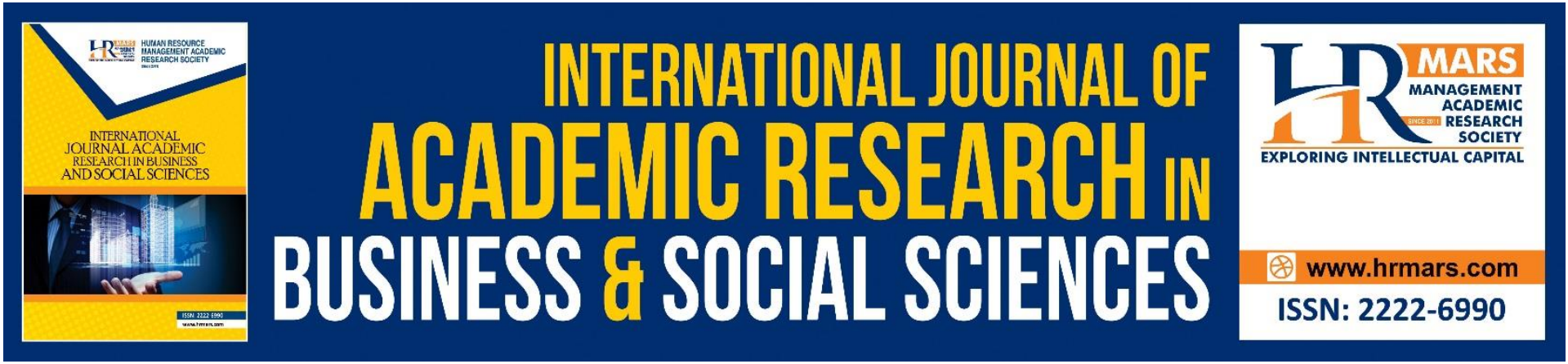

\title{
Opportunities and Challenges in ESL Online Learning Environment: A Review of Literature
}

\section{Amira Dayana Hanafiah \& Azlina Abdul Aziz}

To Link this Article: http://dx.doi.org/10.6007/IJARBSS/v12-i1/12062

DOI:10.6007/IJARBSS/v12-i1/12062

Received: 08 November 2021, Revised: 11 December 2021, Accepted: 30 December 2021

Published Online: 17 January 2022

In-Text Citation: (Hanafiah \& Aziz, 2022)

To Cite this Article: Hanafiah, A. D., \& Aziz, A. A. (2022). Opportunities and Challenges in ESL Online Learning Environment: A Review of Literature. International Journal of Academic Research in Business and Social Sciences, 12(1), 1721-1730.

Copyright: (c) 2022 The Author(s)

Published by Human Resource Management Academic Research Society (www.hrmars.com)

This article is published under the Creative Commons Attribution (CC BY 4.0) license. Anyone may reproduce, distribute, translate and create derivative works of this article (for both commercial and non0-commercial purposes), subject to full attribution to the original publication and authors. The full terms of this license may be seen at: http://creativecommons.org/licences/by/4.0/legalcode

Vol. 12, No. 1, 2022, Pg. 1721- 1730

http://hrmars.com/index.php/pages/detail/IJARBSS

Full Terms \& Conditions of access and use can be found at http://hrmars.com/index.php/pages/detail/publication-ethics 


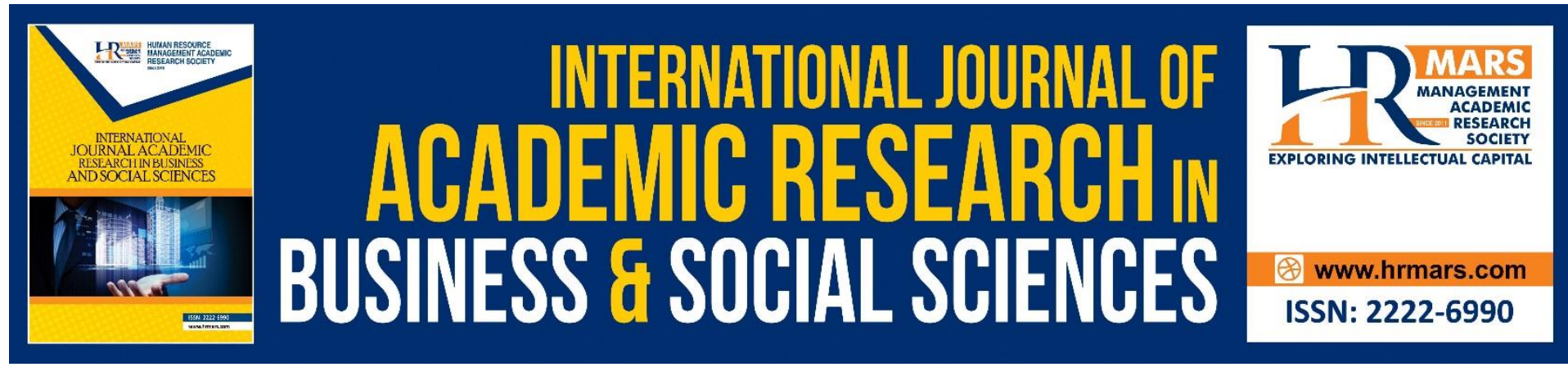

\title{
Opportunities and Challenges in ESL Online Learning Environment: A Review of Literature
}

\author{
Amira Dayana Hanafiah \& Azlina Abdul Aziz \\ Faculty of Education, Universiti Kebangsaan Malaysia \\ Email: amiradayana97@gmail.com
}

\begin{abstract}
In the era of globalization, there is no doubt that online learning can offer a meaningful learning experience to the students. Nowadays, with the rapid advancement of technology that cannot be controlled, educational institutions need to produce individuals that are highly skilled in ICT. The transformation from traditional talk and chalk method to incorporating ICT in the classroom is a good indicator that educators have realized the importance of $21^{\text {st }}$ century education. In the context of English as a Second Language (ESL) specifically, there are many online innovative pedagogical tools that can be utilized by instructors to improve students' language mastery. This paper aims to review the opportunities and challenges in ESL online learning environment. Therefore, the researchers use journal articles and conference proceedings to find information on the related data. This study concludes that even though there are challenges that hinder the effectiveness of online learning, there are still many opportunities in ESL online learning environment that should be put to good use.
\end{abstract}

Keywords: Online Learning Environment, Opportunities, Challenges, Pandemic Panic, Students' Readiness.

\section{Introduction}

Today, digital information can be accessed everywhere at any time to almost everyone making online learning the best option for people to practice lifelong learning. According to Güzer and Caner (as cited in Halim \& Hashim, 2019), new terms in distance education such as online learning, e-learning or web-based learning are the results of the rapid technological change. The word "technology" has become very familiar and commonly used in the education sector because of its effectiveness in improving the teaching and learning experience.

The role of teachers have evolved from being instructors and managers to facilitators (Tigarajan, Yunus \& Aziz, 2016). The $21^{\text {st }}$ century classroom pitches the idea of a studentcentered learning environment whereby student are given autonomy in their learning and teachers focus on monitoring the students' progress and performance. According to Rahman, Yunus and Hashim (2019), educators and stakeholders are exploring the best pedagogical tools to provide meaningful learning experiences for students in this $21^{\text {st }}$-century education.

Many educators continue to practice technology-based activities in teaching and learning and researches have proven that these activities support student learning (Thang et 
al., as cited in Halim \& Hashim, 2019). Yeop (2019, as cited in Rahman et al., 2019) recommends technology integration in the syllabus, instructions and the teaching and learning approach to cater to the demands of $21^{\text {st }}$-century learning. Jemima, Melor and Jamal (2017, as cited in Halim \& Hashim, 2019) stated that educators are aware that nowadays, students need to be well equipped with the $21^{\text {st }}$-century skills.

The outbreak of COVID-19 has a growing impact on the global economy and how long this pandemic will last is still unpredictable. China, which is believed to be the country of origin for COVID-19 had introduced an emergency policy initiative known as "Suspending Classes Without Stopping Learning" to ensure that learning continues even when schools across the country are closed down (Zhang et al., 2020).

The Ministry of Education in Malaysia has prepared a detailed plan that consists of skills and competencies that are aligned with the National Education Philosophy known as Malaysian Education Blueprint 2013-2025 (Halim \& Hashim, 2019). Those skills would equip the students with the knowledge and skills needed to face the challenges of the fast-changing world. Globalized Online Learning, an ICT based-learning is emphasized in the blueprint and declared in the $9^{\text {th }}$ shift division (Rahman et al., 2019).

According to Abdullah, Ismail, Mohamad, Razak, Harun, Musa and Yeong (2020), the Ministry of Higher Education is taking measures such as finding technology drivers of the present and the future to prevent and ensure future epidemics and pandemics will be managed better. This unpredictable crisis can be turned into opportunities to improve online learning from home (Abdullah et al., 2020). School closures in Malaysia have affected an estimated number of 5 million school students and 1.2 million university students in Malaysia (Rahman, 2020). Even though distance learning has been practiced before in Malaysia since the 1990s, but the era has changed with the rapid digital transformations and new pedagogical innovations (Abdullah et al., 2020).

The pandemic panic refers to the common psychological reactions of fear and panic when facing a pandemic (Abdullah et al., 2020). These reactions are expected in the challenging times causing people to fear a shortage of food supply and health-related products (Abdullah et al., 2020). The disruption to routine in daily lives due to Movement Control Order and financial issues increases the fear and anxiety among the public (Wong \& Sam, as cited in Abdullah et al., 2020). In Malaysia, there are very limited studies on early interventions conducted specifically in the education sector to handle psychological problems due to COVID-19. However, the public in Malaysia can reach for help from government and non-governmental organizations that are offering psychological aid through tele-counselling and hotline services (Abdullah et al., 2020).

Online learning in the ESL classroom exposes students to new pedagogical innovations with the aid of technology which allows quick mastery of language skills and increased students' motivation and excitement (Mohamad, Ghazali \& Hashim, 2018). ESL learners can search and retrieve a wide variety of learning resources that are accessible online without limits (Ramsin \& Mayall, 2019). This is an advantage for ESL learners especially in the $21^{\text {st }}$ century whereby the focus of language learning is no longer entirely on grammar but rather the ability of the learners to practice the language proficiently and effectively (Ramsin \& Mayall, 2019).

Online learning in the time of crisis is a must to ensure learning is not suspended (Zhang et al., 2020). There is an immense need to use virtual technologies in education and face the challenges of ensuring students' and teachers' readiness for online learning (Abdullah et al., 2020). It is very important for institutions to examine and assess students' readiness to 
online learning before planning how to conduct online teaching effectively (Ramsin \& Mayall, 2019). Students need to be confident and willing to use online learning tools to ensure effective learning can take place (Ramsin \& Mayall, 2019).

Technology has changed the way information is disseminated and communication is taken place (Topacio, 2018). E-literacy among students will help prepare them for life-long learning and encourage them to take ownership of their learning (Topacio, 2018). Online learning overcomes the boundaries of time and place and encourages communication and knowledge sharing among the virtual community (Ramsin \& Mayall, 2019). The constraint of optimising online learning in Malaysia is changing the mindset of educators and teachers and making them realise that it is not just an option for tech-savvy educators but it is compulsory for everyone to adopt online learning (Rahman, 2020).

The use of online learning in the context of ESL is becoming more prominent and research in this area is urgently needed. The traditional chalk and talk method is now irrelevant for students in the $21^{\text {st }}$ century (Zakaria et al., 2017). This is because learning without technology prevents students from opportunities of developing the 4Cs which are collaboration, critical thinking, creative thinking and communication (Zakaria et al., 2017). In addition, the COVID-19 global outbreak pushes educators to test, practice and evaluate online learning to ensure students get the best experience in the ESL online learning environment. This paper discusses the definition of online learning environment, opportunities and challenges in ESL online learning environment.

\section{Online Learning Environment}

Most researchers are still working on reaching a consensus on the definition of online learning. Several researchers defined online learning as "an access to learning through the use of technology" (Benson, 2002; Conrad, 2002; Carliner 2004, as cited in Zhao \& Mei, 2016). Certain researchers claim that online learning originates from distance learning and it is an improved version of the latter (Hiltz \& Turoff, 2005 as cited in Zhao \& Mei, 2016). The term 'online learning environment' in this paper refers to any learning environment which utilizes electronic devices in the instructional delivery system (Zhao \& Mei, 2016).

\section{Opportunities in ESL Online Learning Environment}

Based on previous studies, online learning has become very important to support learning without boundaries and lifelong learning. Recent studies have shown that not all countries are fully prepared to conduct online learning. In the ESL context, there are many websites, applications and resources online that can be accessed to ensure continuous learning takes place. The incorporation of online learning has positively transformed the teaching styles, curriculum design and the concept of language learning (Halim \& Hashim, 2019). Besides, studies have shown that there are many opportunities in ESL online learning environment such as promoting independent learning, enhancing students' motivation and encouraging collaboration.

\section{Independent Learning}

Integrating technology in the English curriculum helps to enhance independent learning in students and promote life-long learning (Topacio, 2018). For example, students can express their ideas, evaluate facts and opinions and share information with their peers via online (Topacio, 2018). Students in the $21^{\text {st }}$ century are encouraged to utilize online learning activities such as online games which can develop learners' language mastery 
(Yaacob \& Yunus, 2019). Online games can be used to enhance learning in the ESL classroom. Students become more confident in learning because they are trained to be independent learners with online games that require them to take charge of the situations (Yaacob \& Yunus, 2019). Also, when students participate in online learning, they become less anxious, more confident and show desired behaviours as they do not feel scared of using the English language virtually (Yaacob \& Yunus, 2019).

Students especially from Gen-Z require flexibility in learning that suits best with their learning styles (Hashim, 2018). They want options in learning and prefer personalized learning, making them more independent and responsible for their own learning (Hashim, 2018). The integration of technology in learning arouse students' interest, making them more independent in developing language learning on their own (Hashim, Rafiq \& Yunus, 2019). The nature of online learning that requires students' commitment to find materials online helps to improve students' self-discovery skills and make them independent learners (Zakaria et al., 2017). Students become more independent as the interactions between teachers and students are limited to discussions and communications online (Robinson, Kilgore \& Warren, 2017).

\section{Motivation}

The use of online learning in ESL classroom can help students to quickly master the language skills through the exposure of various interactive online learning tools, making students excited and motivated for an extended period (Mohammad et al., 2018). Digital storytelling is one of the growing online language learning tools that is proven effective in increasing students' motivation (Zakaria \& Aziz, 2019). This method increases students' motivation to write and significantly improves their writing skills as they learn writing in a fun way (Zakaria \& Aziz). Research had also found out that students are more excited in lessons that involve the use of technology (Zakaria \& Aziz, 2019). Another study found out that students must be self-motivated because they have to take charge of their learning in online learning environment (Ramsin \& Mayall, 2019). Therefore, it is crucial for students in online learning environments to actively monitor their own progress, search for information required to complete their tasks on their own and take appropriate action in facing any hurdle that arises from their learning (Ramsin \& Mayall, 2019). A study found out that students' achievement in grammar is higher when students are motivated to win the online game (Hashim et al., 2019).

The motivation of students can be improved by having a clear course structure and pre course briefing, establishing learning objectives and providing enough support and resources (Shukla, Dosaya, Nirban \& Vavilala, 2020). Constant interaction and engagement between teachers and students and among students themselves increase students' motivation in learning the language in the online learning environment (Shukla et al., 2020). Students' motivation to learn further is relatively higher when they are interested in the teaching and learning process (Zakaria et al., 2017). A study revealed that students are keen to learn when anticipatory set using technology in the lesson is introduced by the teachers (Zakaria et al., 2017). The students' drive to learn improves their intrinsic motivation, making them more participative in the lessons (Zakaria et al., 2017). Not only students are motivated to learn in the online learning environment, but teachers also feel motivated to constantly upgrade their skills and knowledge to integrate the technology in the lessons as they are relieved with the support provided by the communities. In order for students to demonstrate their presence in a virtual environment, they have to show their motivation by actively 
participating in the learning activities such as posting comments, responding to opinions of others, acknowledging teachers' instruction and engaging with peers in group work (Kehrward, 2008 as cited in Sun \& Chen, 2016).

\section{Collaborative Learning}

The online learning environment allows students and teachers to apply technologies in the teaching and learning process, collaborating with others and taking opportunities of the time flexibility (Robinson et al., 2017). There are many online pedagogical tools available for synchronous learning that enables collaboration opportunities such as Blackboard Collaborate, Adobe Training and GoToTraining (Robinson et al., 2017). It is very crucial to provide adequate support for teachers to constantly fine new creative and collaborative ways to conduct online lessons (Robinson et al., 2017). The teacher should take the role of a facilitator that applies constructivism theory in the online learning environment through collaborative activities that supports learning outcomes (Robinson et al., 2017). Social constructivism emphasizes on collaboration, communication and interactions among students which can be implemented in the online learning environment by encouraging students to interact with peers in the process of knowledge construction (Askeroth \& Richardson, 2019).

If students are learning online asynchronously, they are not restricted to time and place and they are available to access global resources and be a part of a strong learning community (Shukla et al., 2020). Collaboration among the students can be achieved through constant interactions, communication, sharing feedbacks and active learning (Shukla et al., 2020). Also, online learning enables students to construct their own knowledge and perspectives in a small group. The focus of $21^{\text {st }}$-century education is to produce individuals with 'a culture of inquiry' and knowledge generation through online learning activities that promote collaboration, communication, creativity and critical thinking (Zakaria et al., 2017).

\section{Challenges of Online Learning Environment in ESL classroom}

Although there are many opportunities in ESL online learning environment, there are many challenges faced by ESL learners and teachers to ensure this $21^{\text {st }}$-century learning approach a success. The challenges could hinder the effectiveness of online learning if there is no specific action taken to address the problems. The challenges of online learning environment in ESL classroom includes limited time, technological issues and online-related distractions. Even though online learning has enhanced the way we learn from the past but there should be constant evaluation conducted to improve the online learning environment specifically in ESL classrooms.

\section{Time Consuming}

In an online learning environment particularly in the ESL context, students claimed that they are pressured by the limited time allocated to complete an assignment (Topacio, 2018). For example, students have only a few hours a day to write essays and submit them online. In traditional face-to-face classrooms, students are given a day or more to write and submit essays (Topacio, 2018). Past studies have found that online learning is time-consuming in comparison to traditional face-to-face classrooms (Sun \& Chen, 2016). This is because it takes a lot of time for teachers to grade assignments and examinations, provide feedbacks and responding to questions (Sun \& Chen, 2016). Apart from that, teachers also have to prepare teaching materials before conducting lessons such as lecture videos, online 
presentations, individual or group assignments with clear instructions and submission dates as well as guidance on how to utilize technology for online learning (Sun \& Chen, 2016). Besides, online instructors have to provide timely feedbacks to their students and regarding their learning progress, making time pressure challenge more evident in the online learning environment (Sun \& Chen, 2016).

Another study found out that there are lecturers that receive very little support and help from educational institutions to conduct online classes (Sun \& Chen, 2016). Furthermore, the communication of individuals in the online learning environment is normally limited to emails, forum postings and comments which is less interactive in comparison to physical face to face interactions (Robinson et al., 2017). The heavy-content of online courses offers very little time for online learners to have meaningful interactions (Robinson et al., 2017). Also, the online learning environment in the ESL classroom requires a great amount of commitment from all the parties involved to establish a collaborative relationship. Instructors can choose to conduct synchronous or asynchronous activities or both but studies have found that synchronous activities help learners to reduce the delay factor (Robinson et al., 2017). ESL teachers need to constantly remind the students about deadlines and where to retrieve certain materials and assignments which can be time consuming (Rusli \& Hashim, 2018).

\section{Technological Issues}

Technology failure is a challenge for instructors and learners as learning is suspended. The most common technological issues in an online learning environment are bandwidth problems, slow internet connections and lag during online meetings (Robinson et al., 2017). In certain cases, a large number of students attending websites such as online discussion forums or Edmodo at the same time will make the entire network lag (Halim \& Hashim, 2019). Students that are doing online learning but still on campus face the issue of restricted bandwidth whereby institutions refrain students from entering certain websites although it is for academic purposes (Halim \& Hashim, 2019). Apart from that, there is also an internet connectivity problem in rural areas in Kelantan, Malaysia. The teachers in one of the rural schools in Kelantan mentioned that poor internet connection and limited computers are among the challenges they face to provide an online learning platform for the students (Zakaria et al., 2017). Another problem that occurs from technological faulty is that students make it an excuse when they submit their assignments late or unable to be present in a synchronous virtual discussion (Rusli \& Hashim, 2018).

Although most students nowadays own a laptop or have access to computers and the internet, there are still students that have to learn online using their mobile devices. The nature of mobile devices that have smaller screens, shorter battery lifespan, smaller storage and slow downloading are constraints that certain students have to face (Georgiev et al., 2004; Corlett et al., 2005; Franklin et al., 2007 as cited in Hashim, Yunus, Embi \& Ozir, 2017). Furthermore, students using mobile devices to online learning have to face the limited availability of broadband wireless access, making the online learning process tougher (Hashim et al., 2017). Students with mobile devices that have smaller storage can download learning materials and online store what is needed and commonly used in the learning process (Hashim et al., 2017). Also, students have to ensure that the downloaded materials can be accessed even when there is no or slow internet connection (Hashim et al., 2017). 


\section{Online-related Distractions}

Another challenge of learning in an online learning environment in ESL classrooms is the online-related distractions faced primarily by the students. These distractions hinder the success of online learning (Topacio, 2018). During online learning, students can also be actively chatting with friends on social media, making purchases online, playing games and many other activities (Halim \& Hashim, 2019). Students waste a lot of time on those features which causes them to lose concentration on the actual tasks given by instructors on Facebook groups (Halim \& Hashim, 2019). Ali's study in 2014 found that the use of Instagram for language learning could be challenging for students that feel reluctant to participate in the online discussions due to uncertainty about the kind of postings that they should do (Halim \& Hashim, 2019). Another study reveals that students become easily distracted if they are not clear with the rules of the online games (Yaacob \& Yunus, 2019).

Multitasking also can take a toll on students' concentration, making them distracted and unable to fully retain the knowledge learnt (Hashim et al., 2017). Gen-Z students that are born roughly between 1995 to 2010 have a shorter attention span due to the multitasking they performed (Hashim, 2018). This is because this generation is easy to get bored and excited to move on to the next activity (Hashim, 2018). Therefore, 'bite-sized learning' is suitable for this generation to ensure they stay focus and motivated during the online lesson (Hashim, 2018). Some students claimed that they are often distracted by scrolling their social media accounts, watching entertainment videos and playing online games during the lessons (Topacio, 2018). Online learning gives students the time flexibility and frees them from direct criticism making them more susceptible to distractions on the internet. Some students struggle to focus in the online learning environment as they are not monitored by teachers and they are not physically present in an academic setting (Topacio, 2018).

\section{Conclusion}

The study contributes to the understanding of the opportunities and challenges of ESL learning environment. All in all, there is no doubt that online learning is becoming very crucial to ensure learning is not suspended during the pandemic. Even though, not all instructors and students are fully ready to embrace online learning and teaching before, but the unfortunate situation sends an important message to all that online learning is the future of learning. Everyone from teachers, lecturers, students and parents have to constantly upgrade their skills and knowledge on ICT to ensure the $21^{\text {st }}$-century education in Malaysia will be a success. Also, the government has to ensure that all students in Malaysia are equipped with laptops and able to access the internet regardless of whether they are in rural or urban areas. It is crucial for everyone to act upon to mitigate the learning loss due to COVID-19 by utilizing the online pedagogical tools available. Language can be learnt in many ways such as literature, music, movies, games, educational videos and many more. Therefore, teachers should be creative in utilizing all the applications and websites available online to enhance students' motivation to learn and develop students' mastery of the English language.

\section{References}

Abdullah, J. M., Ismail, W. F. N., Mohamad, I., Ab Razak, A., Harun, A., Musa, K. I., Lee, Y. Y. (2020). A critical appraisal of COVID-19 in Malaysia and beyond. Malays J Med Sci. 27(2):1-9. https://doi. org/10.21315/mjms2020.27.2.1

Askeroth, J. H., \& Richardson, J. C. (2019). Instructor perceptions of quality learning in MOOCs they teach. Online Learning, 23(4), 135-159. 
Halim, M. S. A. A., \& Hashim, H. (2019). Integrating web 2.0 technology in ESL classroom: A review on the benefits and barriers. Journal of Counseling and Educational Technology, 2(2), 19-26. https://doi.org/10.32698/0421

Hashim, H. (2018). Application of technology in the digital era education. International Journal of Research in Counseling and Education, 2(1), 1-5. https://doi.org/10.24036/002za0002

Hashim, H., Rafiq, R. M., \& Yunus, M. (2019). Improving ESL learners' grammar with gamifiedlearning. Arab World English Journal (AWEJ) Special Issue on CALL, (5) 41-50.

Hashim, H., Yunus, M. M., Embi, M. A., \& Ozir, N. A. M. (2017). Mobile-assisted language learning (MALL) for ESL learners: A review of affordances and constraints. Sains Humanika, 9(1-5), 45-50.

Mohamad, M., Ghazali, N., \& Hashim, H. (2018). Secondary school students' perceptions on the use of Google+ towards improving ESL writing skills. International Journal of Emerging Technologies in Learning (iJET), 13(09), 224-238.

Rahman D. (2020). A reckoning for online learning in times of crisis. The Star. Retrieved from https://www.thestar.com.my/opinion/columnists/whats-yourstatus/2020/03/24/a-reckoning-for-online-learning-in-times-of-crisis

Rahman, S. F. A., Yunus, M, M., \& Hashim, H. (2019). A Technology Acceptance Model (TAM): Malaysian ESL lecturers' attitude in adapting flipped learning. Jurnal Pendidikan Malaysia, 44(1), 43-54. https://doi.org/10.17576/jpen-2019-44.01si-04

Ramsin, A., \& Mayall, H. J. (2019). Assessing ESL learners' online learning self-efficacy in Thailand: Are they ready? Journal of Information Technology Education: Research, 18, 467-479. https://doi.org/10.28945/4452

Robinson, H. A., Kilgore, W., \& Warren, S. J. (2017). Care, communication, learner support: Designing meaningful online collaborative learning. Online Learning, 21(4), 29-51.

Rusli, R., \& Hashim, H. (2018). Implementing an online learning platform in an English as a second language context: Analyses of blended courses issues and solution. International Journal of Engineering \& Technology, 7, 65-68.

Shukla, T., Dosaya, D., Nirban, V. S., \& Vavilala, M. P. (2020). Factors extraction of effective teaching-learning in online and conventional classrooms. International Journal of Information and Education Technology, 10(6), 422-427.

Sun, A., \& Chen, X. (2016). Online education and its effective practice: A research review. Journal of Information Technology Education: Research, 15, 157-190.

Tigarajan, D., Yunus, M. M., \& Aziz, A. A. (2016). What good language learners do to learn English language. Journal of Education and Social Sciences, 5(2), 132-145.

Topacio, K. N. M. (2018). Exploring the use of online educational platform in teaching writing among ESL students. Journal of Language and Linguistic Studies, 14(21), 86-101.

Yaccob, N. S., \& Yunus, M. M. (2019). Language games in teaching and learning english grammar: A literature review. Arab World English Journal, 10 (1) 209 -217. https://dx.doi.org/10.24093/awej/vol10no1.18

Zakaria, M. A., \& Aziz, A. A. (2019). The Impact of Digital Storytelling on ESL Narrative Writing Skill. Arab World English Journal (AWEJ) Special Issue on CALL (5). 319- 332. DOI: https://dx.doi.org/10.24093/awej/call5.22

Zakaria, A. A., Di, L. Y., \& Yunus, M. M. (2017). 21st century education in teaching English as a second language (ESL) in Malaysia. In Prosiding Seminar Serantau (Vol. 8, pp. 382-390). 
Zhang, W., Wang, Y., Yang, L., \& Wang, C. (2020). Suspending classes without stopping learning: China's education emergency management policy in the COVID-19 outbreak. Journal of Risk and Financial Management, 13(3), 55. https://doi.org/10.3390/jrfm13030055

Zhao, C., \& Mei, Z. (2016). A case study of American and Chinese college students' motivation differences in online learning environment. Journal of Education and Learning, 5(4), 104-112. https://doi.org/10.5539/jel.v5n4p104 